\title{
Hispanismes
}

Revue de la Société des Hispanistes Français

\section{Laços de família de Clarice Lispector}

\section{A flor e a fera}

Uma leitura de "Mistério em São Cristóvão", de Clarice Lispector

La fleur et la bête. Une lecture de "Mistério en São Cristóvão", de Clarice

Lispector

La flor y la bestia. Una lectura de "Mistério en São Cristóvão", de Clarice

Lispector

The Flower and the Beast. A Reading of "Mistério en São Cristóvão", by Clarice

Lispector

\section{Gilberto Araújo}

\section{CpenEdition}

\section{Journals}

\section{Edição electrónica}

URL: https://journals.openedition.org/hispanismes/653

DOI: 10.4000/hispanismes.653

ISSN: 2270-0765

\section{Editora}

Société des Hispanistes Français

\section{Refêrencia eletrónica}

Gilberto Araújo, «A flor e a fera », Hispanismes [En ligne], 15 | 2020, mis en ligne le 01 juin 2020, consulté le 31 juillet 2021. URL : http://journals.openedition.org/hispanismes/653 ; DOI : https:// doi.org/10.4000/hispanismes.653

Este documento foi criado de forma automática no dia 31 julho 2021.

\section{$\oplus \Theta \Theta$}

Les contenus de cette revue sont mis à disposition selon les termes de la Licence Creative Commons Attribution - Pas d'Utilisation Commerciale - Pas de Modification 4.0 International. 


\title{
A flor e a fera
}

\author{
Uma leitura de "Mistério em São Cristóvão", de Clarice Lispector \\ La fleur et la bête. Une lecture de "Mistério en São Cristóvão", de Clarice \\ Lispector \\ La flor y la bestia. Una lectura de "Mistério en São Cristóvão", de Clarice \\ Lispector
}

The Flower and the Beast. A Reading of "Mistério en São Cristóvão", by Clarice

Lispector

\section{Gilberto Araújo}

1 Em 30 de dezembro de 1951, a seção "Letras e Artes" do jornal Diário Carioca anunciava o livro Mistério em São Cristóvão, de Clarice Lispector ${ }^{1}$. Logo no início do ano seguinte, em 6 de janeiro de 1952, o suplemento Letras e Artes, desta vez do periódico A Manhã, propagandeava o mesmo título na coluna "Livros anunciados para este ano" 2 o Diário Carioca volta a divulgar a publicação em 11 de maio de 1952 para, cerca de um mês depois, em 15 de junho, informar que a escritora alterara o nome do volume para Alguns contos, a ser editado na coleção "Cadernos de Cultura", organizada por José Simeão Leal para o Serviço de Documentação do Ministério da Educação e Cultura ${ }^{3}$, sem apresentar explicações para a mudança de nome.

2 Lançado em meados de 1952, o recém-batizado Alguns contos logo receberia atenção do crítico romeno-brasileiro ştefan Baciu, no artigo "Apontamentos sobre três contistas brasileiros", encartado no Letras e Artes de A Manhã em 21 de setembro daquele ano. 0 analista considera o título anterior "mais feliz" e reconhece que a vida familiar "ganha nestes contos uma terrível força dramática, exatamente pela arte de situar estes pormenores aparentemente sem importância, no lugar devido, para fechar o conto com uma exatidão raramente encontrada" 5 .

3 A despeito de não mais nomear a coletânea, "Mistério em São Cristóvão", um dos menores textos do conjunto, mantém a proeminência em Alguns contos, inaugurando o livro. A bem da verdade, o novo título harmonizava-se ao desprendimento espaçotemporal da ficção clariciana e amarrava melhor as outras peças do volume, a 
saber: "Os laços de família", "Começos de uma fortuna", “Amor", "Uma galinha" e "O jantar". A esses seis contos se agregariam outros para compor, em 1960, Laços de família, denominação menos arriscada do ponto de vista editorial e mais compatível com abrangência temática da obra. Contudo, esta publicação, mais conhecida do leitor contemporâneo, deslocou "Mistério em São Cristóvão" da primeira para a antepenúltima posição, minimizando a relevância que Clarice, a crítica literária e a imprensa da década de 1950 lhe conferiram.

4 Pequena amostragem desse destaque: em 20 de setembro de $1953^{6}$, o texto preenche a coluna "O conto da semana", aos cuidados de Aurélio Buarque de Hollanda Ferreira para o "Suplemento Literário" do Diário de Notícias. No prestigioso Suplemento Dominical do Jornal do Brasil", de 29 de agosto de 1959, "Mistério em São Cristóvão" é destacado por Assis Brasil como índice de nova maneira de narrar, partilhada, segundo o crítico, com Samuel Rawet, José Louzeiro, José J. Veiga, Jorge Medauar.

5 Cinco anos depois do lançamento de Laços de familia, Léo Gilson Ribeiro, em estudo de 1965 no Correio da Manhã, confere relevo a "Mistério em São Cristóvão", "uma evocação fantasmagórica do carnaval carioca na noite do subúrbio outrora aristocrático", escrita na "Suíça branca, geométrica, de píncaros dos Alpes nevados". Ao enfatizar o distanciamento entre os espaços da escrita, a cidade de Berna, e da narrativa, um bairro do Rio de Janeiro, o articulista sublinha a inquietação despertada pelo conto, particularidade que a autora confidenciaria em "Fundo de gaveta", preciosa coleção de crônicas e depoimentos enfeixados na segunda parte de seu Legião estrangeira (1964):

"Mistério em São Cristóvão" é mistério para mim: fui escrevendo tranquilamente como quem desenrola um novelo de linha. Não encontrei a menor dificuldade. Creio que a ausência de dificuldade veio da própria concepção do conto: sua atmosfera talvez precisasse dessa minha atitude de isenção, de certa não participação. A falta de dificuldade é capaz de ter sido técnica interna, modo de abordar, delicadeza, distração fingida. ${ }^{9}$

6 Anos depois, Alexandre Eulalio reincide na riqueza da narrativa: "Das seis histórias que Clarice Lispector publicou n'Os Cadernos de Cultura, a primeira, "Mistério em São Cristóvão", talvez seja a que mais alcance um plano de sugestão poética para o leitor." ${ }^{10}$.

o breve retrospecto é sintomático de quanto o conto concretiza uma idiossincrasia da ficção de Clarice Lispector, a ponto de a escritora desejá-lo na capa do livro. Isso se deve, em nosso entendimento, à maneira sintética com que o texto elabora a epifania, tornando-se uma espécie de súmula poética da obra de Clarice.

8 Já virou senso comum referir-se à epifania vivenciada pelos personagens da escritora: $\mathrm{o}$ momento de revelação deriva, com grande frequência, de uma experiência de alteridade em que o sujeito acessa zonas desconhecidas ou inomináveis de si, do outro, da linguagem, do mundo, da vida. Pode-se correr o risco de apontar que, grosso modo, esse é o denominador comum de toda ficção clariciana e, por esse motivo, parece-nos de pouca rentabilidade crítica insistir em seu estudo como tema ou motivo, visto que ele sempre nos levará ao mesmo lugar. Por outro lado, se o tomarmos como procedimento ou escritura, poderemos aferir a maestria com que Clarice organiza a "verdade universal" de sua obra na materialidade particular de cada texto.

9 Parcela da fortuna crítica reclamou atenção à forma literária como instância fundamental da epifania. Já na estreia de Clarice com Perto do coração selvagem (1942), Antonio Candido observara que sua prosa "colocou seriamente o problema do estilo e da expressão. Sobretudo desta"1 ${ }^{11}$. Dez anos depois, por ocasião do lançamento de Alguns 
contos, Sérgio Milliet ressaltava sua "constante deformação sintática e vocabular"12. Affonso Romano de Sant'anna também reconhece que, "enquanto rito, essa narrativa epifânica se repete a si mesma, repetindo os mesmos lugares, como a quase rigidez do rito sempre velho e novo, como a girar uma série de símbolos em torno de um mesmo eixo enfatizando sua insuperável circularidade" ${ }^{13}$. Na mesma direção, afirma Fábio Lucas: "a ficção de Clarice Lispector é primordialmente um modo de narrar"14.

10 Sobressai-se, nessa linha de abordagem, A escritura de Clarice Lispector, de Olga de Sá. Após minuciar como James Joyce transformou a epifania em "técnica literária" ${ }^{15}$, a autora registra que Affonso Romano Sant'Anna entende o conceito, em Clarice, "ora como técnica ora como mero motivo" ${ }^{16}$. Radicalizando a pesquisa do mineiro, ela defende que a "escritura epifânica é, portanto, do domínio do narrador"17. Em prefácio ao livro de Olga, Haroldo de Campos também compreende a epifania como procedimento e pondera que, apesar de o texto de Clarice ser antes uma "literatura do significado", sua escritura se "encaminha "para o polo da sensibilidade e se coagula em superícones, reforçados por paronomásias, sinestesias, anagramas, aliterações”"18.

11 Essa ênfase no processo de construção da epifania coaduna-se, em larga medida, com o que Clarice designou de "distração fingida" na seção "Fundo de gaveta". No mesmo segmento, ela arremata:

Não é fácil lembrar-me de como e por que escrevi um conto ou um romance. Depois que despegam de mim, também eu os estranho. Não se trata de 'transe', mas a concentração no escrever parece tirar a atenção do que não tenha sido o escrever propriamente dito ${ }^{19}$.

12 Considerada a "concentração no escrever", passamos, então, a percorrer alguns caminhos de elaboração discursiva do percurso epifânico em "Mistério em São Cristóvão", selecionado pela trajetória destacada na contística clariciana. Para tanto, investigaremos a plasticidade do espaço literário no texto, a caracterização simbólica das personagens, a exploração do ritmo e da camada morfossemântica da narrativa, bem como algumas piscadelas intertextuais. Vamos ao início do conto:

Numa noite de maio - os jacintos rígidos perto da vidraça - a sala de jantar de uma casa estava iluminada e tranquila.

Ao redor da mesa, por um instante imobilizados, achavam-se o pai, a mãe, a avó, três crianças e uma mocinha magra de dezenove anos. O sereno perfumado de São Cristóvão não era perigoso, mas o modo como as pessoas se agrupavam no interior da casa tornava arriscado o que não fosse o seio de uma família numa noite fresca de maio. Nada havia de especial na reunião: acabara-se de jantar e conversava-se ao redor da mesa, os mosquitos em torno da luz. O que tornava particularmente abastada a cena, e tão desabrochado o rosto de cada pessoa, é que depois de muitos anos quase se apalpava afinal o progresso nessa família: pois numa noite de maio, após o jantar, eis que as crianças têm ido diariamente à escola, o pai mantém os negócios, a mãe trabalhou durante anos nos partos e na casa, a mocinha está se equilibrando na delicadeza de sua idade, e a avó atingiu um estado. Sem se dar conta, a família fitava a sala feliz, vigiando o raro instante de maio e sua abundância ${ }^{20}$.

13 O primeiro parágrafo transparece estabilidade, não fossem os jacintos que nele se intrometem com travessões. Contra a monotonia nominal da frase, irrompem as flores que, desligadas de qualquer verbo, não são por isso menos ativas, ao projetarem certa iminência próxima à vidraça. Da sintaxe ao fonema reluz a força opositora das flores: elas semeiam vibração ("perto da vidraça) e estridência ("jacintos rígidos") onde predomina a assonância aberta e nasalizada ("Numa noite de maio [...] a sala de jantar de 
uma casa estava iluminada e tranquila)". Estrídula, a vogal /i/ alastra-se pelo parágrafo em todas as posições possíveis dentro de uma sílaba, replicando sonoramente a potência dos jacintos.

A rosa escolhida por Clarice presta jus à virilidade tanto pelo contorno fálico, quanto por ser uma palavra masculina. Certamente, muitas outras flores possuem esses atributos, mas a maioria, representações gastas do feminino (lírio, por exemplo), não acentuaria o traço varonil. Driblando os clichês de delicadeza, abertura e fragilidade, a escritora salienta a violência em todos os níveis do texto, inclusive no morfológico: além do adjetivo "rígidos" para qualificar os "jacintos", o imponente plural aí empregado contrasta com o singular indefinido de "uma noite de maio" e de "uma sala de jantar", ambas indefesas à soberania floral.

Também se destaca, na abertura do conto, a meticulosa composição do quadro. A escuridão noturna serve de pano de fundo à sala de jantar, que, acesa, torna-se síntese da casa de São Cristóvão, como um palco para a rua: um passante vislumbraria nela o retrato da família, já que o restante parece estar apagado. Logo, a escolha do cômodo não é gratuita, na medida em que radiografa as hierarquias e tensões familiares. Se nas outras partes da habitação, os sujeitos podem se isolar e executar atividades diferentes, na sala de jantar todos convivem e realizam as mesmas ações, o que reproduz e potencializa a configuração doméstica. 0 recinto diferencia-se do estar, onde o grupo não estaria obrigatoriamente junto e haveria espaço para a diversidade de práticas (conversar, ler, dormir, escutar música, ver TV etc.). No jantar, por outro lado, pouco se varia ou improvisa, e essa repetição confinada desevela o esqueleto da moradia. Algo semelhante se verifica no conto "O peru de Natal", de Mário de Andrade, em que a distribuição dos assentos e de tarefas à mesa (como o destrinche da ave natalina) é distintivo importante entre os parentes.

Em "Mistério em São Cristóvão", não temos acesso a esses detalhes, pois o texto se inicia quando a ceia já terminou. Entretanto, a disposição dos parentes na frase inicial do segundo parágrafo deixa rastros dos valores domésticos: o patriarcalismo confirmase na primazia concedida ao pai; o incentivo à reprodução e ao trabalho, na anteposição dos pais à avó; certo desdém à infância/juventude, na apresentação dos filhos apenas ao final da sequência. As três crianças antecipam-se à irmã mais velha, menorizada pelo artigo indefinido e pelo diminutivo. Somente ela tem a idade mencionada: os anódinos 19 anos afastam-na do glamour debutante dos 15 e incitam-na à fase adulta dos 20 anos. Se por um lado ela já foi, por outro ainda não é. Sua condição frágil e mortiça assemelha-se à dos mosquitos em torno da luz.

17 A dança dos insetos também mimetiza os membros da família ao redor da mesa. Em contrapartida, o movimento agitado dos pernilongos perturba a pasmaceira do jantar, corroborando o clima de iminência que subjaz à calmaria inicial. Não por acaso, o rosto de cada pessoa estava "desabrochado", imagem que, aparentando conforto, não deixa de anunciar transformação, comprovada pelo fato de o narrador embaralhar, ao final do segundo parágrafo, a ordenação dos membros da família: antes, tínhamos pai > mãe > avó > crianças > mocinha; agora, crianças > pai > mãe > mocinha > avó.

Tal alteração evidencia facetas fundamentais da narrativa: pai e mãe estão sempre agrupados na mesma ordem, pelos motivos antes apontados. As crianças pulam de uma posição a outra (suas camas são comparadas a trapézios), sem que isso interfira na configuração familiar. $O$ que efetivamente se sobressai na mudança da sequência parental é a aproximação entre a jovem e a avó, antes separadas pelas três crianças. Se 
esse pareamento contrapõe a plenitude da idosa ("atingiu um estado") à irresolução da neta, avizinha-as por ambas não executarem tarefas pragmáticas: as crianças frequentam a escola, o pai trabalha, a mãe cuida do lar; já das outras duas se realçam atributos existenciais, premonizando serem elas as mais diretamente envolvidas na epifania subsequente.

Por mais que esse processo desponte da alteridade, os protagonistas claricianos precisam da solidão, mesmo que provisória, quando menos para enfatizar o iminente choque do contato com o outro. Daí agora todos saírem de cena, a casa dormir, para a adolescente viver a grande experiência:

Passaram-se horas. E quando o silêncio piscava nos vagalumes - as crianças penduradas no sono, a avó ruminando um sonho difícil, os pais cansados, a mocinha adormecida no meio de sua meditação - abriu-se a casa de uma esquina e dela saíram três mascarados.

Um era alto e tinha a cabeça de um galo. Outro era gordo e vestira-se de touro. E o terceiro, mais novo, por falta de ideias, disfarçara-se em cavalheiro antigo e pusera máscara de demônio, através da qual surgiam seus olhos cândidos. Os três mascarados atravessaram a rua em silêncio.

Quando passaram pela casa escura da família, aquele que era um galo e tinha quase todas as ideias do grupo parou e disse:

- Olha só.

Os companheiros, tornados pacientes pela tortura da máscara, olharam e viram uma casa e um jardim. Sentindo-se elegantes e miseráveis, esperaram resignados que o outro completasse o pensamento. Afinal o galo acrescentou:

- Podemos colher jacintos.

Os outros dois não responderam. Aproveitaram a parada para se examinar desolados e procurar um meio de respirar melhor dentro da máscara.

- Um jacinto para cada um pregar na fantasia, concluiu o galo (p. 113).

20 A ciranda familiar continua à noite, movendo os parentes na frase, e diminui a distinção entre pai e mãe, reduzidos a "pais cansados". Quase todos repousam, exceto avó e neta: uma rumina sonho difícil; a outra medita, dados indicativos de um sono ativo, incapaz de paralisar a máquina reflexiva. Essa agitação pulsa no meio circundante, tanto nos vagalumes, espécie mais chamativa do que os mosquitos, quanto nos três mascarados que, ao saírem de uma casa de esquina, provêm de espaço intermediário e fronteiriço, tal como o dormitar das duas personagens e a idade da moça, vizinha de dezenas diferentes.

Concomitantemente, a fauna cresce: das muriçocas e pirilampos, chegamos ao galo e ao touro, com a diferença de serem os insetos reais, e os outros, fantasias. A ave, de voo curto, pertence menos ao ar do que à terra, matéria por sua vez ligada ao touro. Ou seja, a aparição dos mascarados aciona no conto o campo semântico terreno, enquanto os animais precedentes flutuavam em domínio aéreo. Essa descida pontua o abandono da atmosfera amena do jantar pelo confronto com forças agressivas, incontroláveis, diríamos mesmo demoníacas, corporificadas nas máscaras de touro e, evidentemente, de demônio. Com efeito, as três fantasias convocam potências másculas e dionisíacas, reforçadas pela ambientação noturna e pela festa de carnaval fora de época a que os rapazes se dirigiam. A revelação que eles propiciam se torna ainda mais surpreendente, pois não ocorre durante a festa momesca, período em que a brincadeira, a inversão e a sensualidade são esperadas e, talvez por isso, menos extraordinárias. Observe-se que a irrupção dessa zona desconhecida se reflete no discurso, que abdica das descrições lentas por frases curtas e ágeis, fazendo o texto acompanhar a vivência da personagem. 

antes predominavam os pares opositivos (pai $\mathrm{x}$ mãe; pais $\mathrm{x}$ filhos; jovem $\mathrm{x}$ velho; homem x mulher; dentro $\mathrm{x}$ fora; claro $\mathrm{x}$ escuro), os três agora confundem algumas dessas antinomias: são e não são animais, são e não são homens, saem de uma casa na encruzilhada, invadem o jardim, espaço simultaneamente dentro e fora da habitação, parecem perigosos, porém, ao fim e ao cabo, são delicados. Em certa medida, abeiramse das três crianças, inclusive pela referência ao jogo (de um lado, cama-trapézio; doutro, fantasias) e pelo numeral "três". Os pequenos, todavia, constituem um bloco indistinto (inclusive quanto ao gênero ou ao sexo), ao passo que o trio tonifica nas fantasias o atributo da masculinidade, também reverenciada pela ação de atravessarem a rua. Os infantes não têm qualquer atuação na narrativa, enquanto os três de fato alteram um estado de coisas. masculinizante e, portanto, binária. Contudo, na diversidade de suas vestimentas e compleições, os mascarados compendiam figurações do masculino, sem necessariamente fixar ou enaltecer apenas uma delas. Alinhavando vigor e fertilidade, as fantasias envolvem um corpo alto, outro gordo, um terceiro mais novo e não suprimem a delicadeza, a dúvida, a contemplação e o silêncio, em geral ausentes do estereótipo do macho valente, ativo, seguro e tonitroante. A novidade está justamente em tornar possível a convivência de qualidades humanas e animais/animalescas, sutis e agressivas, festivas e compenetradas, conforme prenunciavam os jacintos, que, fálicos e florais, iniciavam a rasura entre masculino e feminino, até mesmo no estrato morfossemântico.

24 A índole plural do trio confirma-se em sua habilidade de metamorfose, incorporando, em maior ou menor escala, características do ente que inspira a vestimenta. 0 rapaz que se fantasia de galo, por exemplo, assume a característica anunciadora da ave: em vez de pressagiar a manhã, aponta os jacintos. Por ser o mais leve e ágil dos três, é o primeiro a se empoleirar no jardim, depois o "touro seguiu-o com dificuldade" (p. 114). Capciosamente, o narrador vai pouco a pouco dissipando a pessoa sob a fantasia de modo a torná-la o animal representado na máscara: o moço que "tinha cabeça de um galo" transforma-se em "aquele que era um galo" e enfim em "o galo". A ocultação do referente inicial como que desobriga os invasores de ser gente, permitindo-lhes agir como bichos, alheios ao conceito de propriedade e liberados para penetrar no jardim.

Todavia, não se deve considerar essa zoomorfização como a supremacia do instinto sobre a razão; afinal, eles ainda são, ou melhor, sempre foram humanos. A ida ao jardim não se dá por motivos associados à reprodução, à fome ou à moradia, conforme se esperaria de um animal. A invasão parece antes corresponder a uma vontade de prazer e beleza. Note-se que, seletivo, o galo não deseja as flores próximas de si, mas o jacinto maior. Apesar de já mascarado, quer aprimorar a fantasia e alegrar os convidados da festa a que se encaminhavam, fazendo com que sua roupa incite a fruição dos outros. Contudo, o acesso a esse estado maior tem um ônus, um "castigo", segundo o narrador, embora não na acepção punitiva ou moralizadora, mas como apelo à tomada de consciência.

De fato, na ficção de Clarice Lispector, os agentes envolvidos no transbordamento de limites, ainda que ínfimos ou convencionais, nunca passam incólumes à transgressão, mesmo quando se trata de pequena travessura carnavalesca. Se a mocinha flagra os três mascarados, também eles a vislumbram atrás da janela, oferecendo-lhe "o espanto, o 
susto causado pelo elemento que transgride aquele espaço cercado, interditado às violações de intimidade" ${ }^{21}$. Surge, então, a via de mão dupla indispensável à epifania, deflagrada, segundo Benedito Nunes, pela "potência mágica do olhar", pelo mútuo “descortínio contemplativo" ${ }^{2}$, ratificado na sequência do conto:

Mal porém quebrara a haste do jacinto maior, o galo interrompeu-se gelado. Os dois outros pararam num suspiro que os mergulhou em sono.

Atrás do vidro escuro da janela estava um rosto branco olhando-os.

O galo imobilizara-se no gesto de quebrar o jacinto. 0 touro quedara-se de mãos ainda erguidas. 0 cavalheiro, exangue sob a máscara, rejuvenescera até encontrar a infância e o seu horror. $O$ rosto atrás da janela olhava.

Nenhum dos quatro saberia quem era o castigo do outro. Os jacintos cada vez mais brancos na escuridão. Paralisados, eles se espiavam.

A simples aproximação de quatro máscaras na noite de maio parecia ter percutido ocos recintos, e mais outros, e mais outros que, sem o instante no jardim, ficariam para sempre nesse perfume que há no ar e na imanência de quatro naturezas que o acaso indicara, assinalando hora e lugar - o mesmo acaso preciso de uma estrela cadente. Os quatro, vindos da realidade, haviam caído nas possibilidades que tem uma noite de maio em São Cristóvão. Cada planta tímida, cada seixo, os sapos roucos aproveitavam a silenciosa confusão para se disporem em melhor lugar tudo no escuro era muda aproximação. Caídos na cilada, eles se olhavam aterrorizados: fora saltada a natureza das coisas e as quatro figuras se espiavam de asas abertas. Um galo, um touro, o demônio e um rosto de moça haviam desatado a maravilha do jardim... Foi quando a grande lua de maio apareceu. (p. 114-115)

É intensa a simbologia de iniciação sexual: a alvura virginal da jovem púbere, os homens fantasiados, o latejar dos vagalumes, os desejos noturnos, o contorno dos jacintos, a flor corrompida, o galo deflorador, a janela metaforizando o hímen, o grito da mocinha, a umidade crescente do jardim. Se o texto abordasse apenas essas questões, teria alcance restrito a um quesito orgânico, quando muito psicanalítico, até porque o desenvolvimento fisiológico da menina independe da aparição dos homens, e faria do "mistério" do título somente uma historinha de aventura noturna. Sem prescindir do aspecto sexual, o conto, na verdade, explora maximamente os desdobramentos de uma célula narrativa mínima, ampliando a mera erotização das flores; daí o galo buscar o "jacinto maior".

Apagadas as luzes, fica mais difícil distinguir a casa do que lhe é exterior, já que tudo se afoga no mesmo negrume. Até o vidro da janela faz-se escuro. Dispostos juntos à vidraça, os jacintos tornam-se guarda-costas da moradia; brancos, discrepam da treva circundante: "Os jacintos cada vez mais brancos na escuridão". Enquanto o jardim está ameaçado pelos aventureiros, "os jacintos estremeciam imunes" (p. 114). Portanto, quebrar o jacinto é expor a vulnerabilidade da fronteira, é desmascarar o caráter ilusório e artificial da divisa. Quando se rompe a barreira, os polos segregados se misturam, as delimitações se esboroam, e tudo entra num intercâmbio incessante em que todo purismo perde relevância: "fora saltada a natureza das coisas". Com isso, a moça, que significativamente abrira a janela antes de dormir, integra-se ao jardim, aos mascarados, e todos eles inevitavelmente sofrem impacto da presença dela, a ponto de passarem a constituir um conjunto de "quatro máscaras". Isso não apenas azeita a oposição entre homem $\mathrm{x}$ mulher, dentro $\mathrm{x}$ fora, humano $\mathrm{x}$ animal, verdadeiro $\mathrm{x}$ fantasioso, como ainda promove a superação da referência ternária: agora o grupo compõe-se de "quatro máscaras". A dialética clariciana é onipresente e constante, não podendo jamais caber numa síntese apaziguadora, como faria supor a configuração trimembre. Tudo existe para ser logo rearranjado, como os laços familiares. Essa 
celebração do dinamismo, enaltecida no final do conto, justificaria os mascarados sumirem depois do grito da jovem: embora decisivos, não precisam permanecer em cena. Valem enquanto duram. A narrativa, lembremos, se passa em São Cristóvão, popularmente conhecido como padroeiro dos viajantes e dos motoristas.

O semblante branco da jovem desempenha, na plasticidade do texto, função semelhante à das flores - a de frisar os contrastes. A mocinha e os mascarados surgem para que o fortuito se torne sublime (não por isso menos pavoroso) aos dois lados: sem os mascarados, as flores não passariam de peças do jardim; sem a menina atrás da vidraça, o "assalto" não seria mais do que um caso alegre de rapazes. Esse efeito especular, mediado pela janela, instaura a reciprocidade necessária à descoberta do outro, em um lampejo que alinhava identificação ("quatro máscaras") e horror, entrega e recuo, medo e fascínio (como a famosa barata de A paixão segundo G.H.). O turning point epifânico não brota apenas da essência da protagonista, tampouco depende da intervenção alheia; a rigor, nasce da confluência entre o âmago e o exterior.

Prova dessa interpenetração está na descrição do encontro dos olhares. Sem que atentemos para a estranheza do instante, lemos que o galo se imobiliza no gesto de quebrar o jacinto e que o touro fica de mãos erguidas. Ao emprestar movimentos humanos a animais que, por sua vez, são humanos fantasiados, o narrador confere naturalidade a declarações que, ao pé da letra, soam absurdas, consoante nota Alexandre Eulalio a respeito deste conto: "A imprevista colocação das peças no tabuleiro de xadrez, criando entre elas formas e relações violentamente novas, acabará mesmo por lançar aqui um clima de alucinação" ${ }^{23}$. Não estamos propriamente no domínio da fábula ou do conto maravilhoso; o cerne narrativo de "Mistério em Cristóvão" é em certa medida até realista. É no âmbito do cotidiano pequeno-burguês que se instalam as fissuras questionadoras desse mesmo real, que deixa de ser unívoco, claro e estanque, para expandir-se ao bizarro e ao espanto. Por isso, ambos os lados sofrem uma acareação espectral: do outro lado da janela, há um rosto branco de mulher; do outro lado da janela, um galo, um touro e um cavalheiro. Onde se supunha ver o interior da casa, o jardim ou apenas o reflexo da própria imagem, abre-se um alçapão, descortinando no espelho-janela camadas indevassáveis a uma observação crua e objetiva. $\mathrm{O}$ assomo desses fantasmas oferece a cada um dos videntes a conviç̧ão de que o reflexo - e de resto, a identidade - nunca prescinde do simulacro, da indecisão entre presença e virtualidade (o narrador chega a falar em quatro espectros). Por isso, onde poderia haver narcisos - flor de nome masculino composto de três sílabas com idêntica disposição das vogais -, surgem jacintos, que, desligados do universo grego, dissipam o narcisismo do rapaz encantado com a própria imagem. A rosa que na mitologia concretizava a morte do jovem é rompida em São Cristóvão para que a moça, multiplicada nos mascarados, veja além de si mesma na superfície da janela.

31 A lubrificação dos limites acomete a paisagem: plantas, pedras, bichos entram numa vibração que se duplica na aparição da lua. Não por outro motivo surgem os sapos, que encharcam de umidade erótica a cena e, anfíbios, celebram a ambiguidade e o trânsito.

Esse animal se destaca ainda por estabelecer intertextualidades, especialmente com os contos de fada, gênero que frequenta com alguma regularidade a ficção de Clarice Lispector, em geral sob clave paródica. Em "A bela e a fera ou A ferida grande demais", por exemplo, o famoso par original se converte em uma madame, à saída do Copacabana Palace, em contato com a ferida na perna de um mendigo. No caso de "Mistério em São Cristóvão", em oposição à generalidade atemporal do "Era uma vez", 
temos as coordenadas específicas de uma noite de maio em um bairro carioca. Em vez de reis e rainhas ou de príncipes e princesas, uma família de classe média. No lugar da linda donzela, uma mocinha sem grandes atrativos; em vez de heróis e caçadores, homens mascarados.

Ao ambientar a narrativa em São Cristóvão, Clarice Lispector presta homenagem enviesada ao universo palaciano dos contos de fadas. Na memória histórico-cultural do Rio de Janeiro, o bairro se caracteriza pela herança monárquica, já que abrigou a Corte Portuguesa, fugida das invasões napoleônicas no início do século XIX. Estabelecido na Quinta da Boa Vista, o palacete imperial era abraçado por extenso parque com lagos e vegetação à moda lusitana. Com a progressiva transferência da elite carioca para a Zona Sul da cidade no começo do século XX, São Cristóvão foi se tornando reduto de imigrantes (muitos, portugueses) menos abastados, atuantes no comércio de secos e molhados ${ }^{24}$. Paulatinamente, a paisagem tornou-se fabril, o bairro esvaziou-se e precarizou-se, mas, hoje em dia, vem sendo revitalizado.

Depois de desembarcar no Brasil e ter vivido na região Nordeste, a família de Clarice Lispector, constituída de judeus perseguidos na Europa, se mudou para o Rio de Janeiro e se instalou "durante poucos meses perto do campo de São Cristóvão, onde havia muitas casas antigas" ${ }^{25}$. A escritora encontrou um bairro simples, algo decadente, habitado pela baixa classe média, distante do passado cortesão. Nessa região, nasce, anos mais tarde, o hoje conhecido Centro de Tradições Nordestinas Luiz Gonzaga, popularmente chamado de Feira de São Cristóvão, que teria inspirado a Macabéa de A hora da estrela (1977). Portanto, conhecedora do subúrbio, Clarice aclimata o "Mistério" em bairro que, emanando o perecimento da nobreza, pode isomorficamente abrigar uma narrativa que rasura a majestade dos contos de fadas. Talvez por isso o narrador mencione, não sem ironia, que, no baile dos mascarados, "os convidados tiveram que abandonar o desejo de torná-los os reis da festa" (p. 115, grifo nosso).

Apesar da ênfase paródica, o conto de Lispector preserva aspectos desse código que, em tese, enodoa. Quase todas as semelhanças com os contos de fadas incidem nos elos entre sexualidade e família. Como em narrativas-matrizes do tipo "Chapeuzinho vermelho", "Branca de Neve" e "Bela adormecida", "Mistério em São Cristóvão" também se debruça sobre as implicações do despertar da sexualidade de uma jovem sobre a estrutura familiar, embora, conforme observamos, esta não seja a única questão levantada pelo conto.

Estudioso do gênero, Bruno Bettelheim destaca a importância do sono em textos como "Branca de Neve" e "A Bela adormecida", em que a lassidão não configura "total passividade ou letargia" ${ }^{26}$, pois fornece a energia e o amadurecimento indispensáveis ao início da puberdade. Trata-se de recolhimento ativo, tal como na meditação noturna da mocinha de São Cristóvão, em exercício de autossondagem que logo desembocará no deparo com os mascarados. A conjugação entre pesquisa interna e atenção ao outro constitui motivo recorrente nos contos de fadas, segundo o mesmo pesquisador:

Mesmo quando uma menina é retratada como voltando-se para dentro de si em sua luta para alcançar a individualidade e o menino como lidando agressivamente com o mundo exterior, esses dois juntos simbolizam os dois modos pelos quais se deve conquistar a individualidade: aprendendo a entender e dominar tanto o mundo interior quanto o exterior. ${ }^{27}$

Nesse sentido, isso que genericamente viemos designando de "o outro" é tão mais atuante quanto mais plural se revelar, franqueando ao eu que com ele se relaciona 
número maior de possibilidades de contato. É por essa razão que, em "Chapeuzinho Vermelho", ocorre o desenvolvimento precoce da menina, já que ela, malgrado a pouca idade, encontra o lobo e o caçador, convivendo muito cedo com a "natureza contraditória do macho ao experimentar todos os aspectos de sua personalidade" ${ }^{28}$. De modo semelhante, a mocinha de São Cristóvão topa com um trio que, originalmente diversificado, ainda se amplifica pela colocação das máscaras: "um alto, um gordo e um jovem, um gordo, um jovem e um alto, desequilíbrio e união" (p. 116). Os três, multiplicados em pelo menos sete (um deles se disfarça de cavalheiro antigo e agrega a máscara de demônio), convocam a menina enclausurada na asséptica e iluminada redoma burguesa a vislumbrar as potencialidades do mundo externo, inclusive em seus meandros selvagens e indômitos. A entrega mútua ("as quatro figuras se espiavam de asas abertas") ecoa no quintal, com os elementos em "muda aproximação", encimada pela lua de maio, convergência apoteótica das luzes que se vinham acendendo no conto. Concomitantemente, há o ápice sonoro no grito da menina, expressão orgástica que se irmana à atmosfera líquida e leitosa da cena.

Dentre os mascarados, o cavalheiro antigo é o que melhor evoca a nobreza heroica dos contos de fada. No entanto, é o mais inofensivo e inerte dos três, sempre último na tomada de decisões encabeçadas pelo galo. Em "Mistério em São Cristóvão", a atividade dos foliões é inversamente proporcional à dimensão de seus figurinos: a ave se sobrepõe ao touro, secundado pelo rapaz com máscara de diabo. Atribuir a menor desenvoltura ao cavalheiro, a despeito de seu semblante demoníaco, ironiza a pretensa hegemonia masculina nos contos de fadas, manifesta em perfis como a do caçador ou do príncipe que acorda a jovem adormecida. Ademais, podemos dizer que, dos três, apenas o galo efetivamente incorpora traços da fantasia; os demais permanecem homens cansados e hesitantes.

Contudo, os salteadores do jardim mantêm, em certa medida, a índole transformadora dos heróis europeus, mas a executam mediante cooperação com o polo feminino. Eles incitam a moça a infringir a pasmaceira familiar, apenas porque, previamente, ela se inclinara na mesma direção, abrindo a janela e respirando "todo o jardim com insatisfação em felicidade", à busca de uma "atitude inteiramente nova" ${ }^{29}$. Em compensação, os rapazes são fundamentais para contrabalançar, no universo masculino, a inocuidade do pai, que, como na maioria das narrativas de fadas, é ineficaz e fraco ${ }^{30}$. Esse vazio paterno - aferível em "Branca de Neve", por exemplo - indiciaria, segundo Bettelheim, a inapetência dos adultos em conduzir o desenvolvimento dos filhos $^{31}$, o que justificaria, na peça clariciana, a desorientação dos pais da mocinha carioca e o sono ininterrupto dos irmãos, surdos ao mistério de seu grito.

Papel mais singular desempenha a avó:

Enquanto isso, a casa dos jacintos iluminara-se toda. A mocinha estava sentada na sala. A avó, com os cabelos brancos entrançados, segurava o copo d'água, a mãe alisava os cabelos escuros da filha, enquanto o pai percorria a casa. A mocinha nada sabia explicar: parecia ter dito tudo no grito. Seu rosto apequenara-se claro - toda a construção laboriosa de sua idade se desfizera, ela era de novo uma menina. Mas na imagem rejuvenescida de mais de uma época, para o horror da família, um fio branco aparecera entre os cabelos da fronte. Como persistisse em olhar em direção da janela, deixaram-na sentada a repousar, e, com castiçais na mão, estremecendo de frio nas camisolas, saíram em expedição pelo jardim.

Em breve as velas se espalhavam dançando na escuridão. Heras aclaradas se encolhiam, os sapos saltavam iluminados entre os pés, frutos se douravam por um instante entre as folhas. 0 jardim, despertado no sonho, ora se engrandecia ora se 
extinguia; borboletas voavam sonâmbulas. Finalmente a velha, boa conhecedora dos canteiros, apontou o único sinal visível no jardim que se esquivava: o jacinto ainda vivo quebrado no talo... Então era verdade: alguma coisa sucedera. Voltaram, iluminaram a casa toda e passaram o resto da noite a esperar.

Só as três crianças dormiam ainda mais profundamente. A mocinha aos poucos recuperou sua verdadeira idade.

Somente ela não vivia a perscrutar. Mas os outros, que nada tinham visto, tornaram-se atentos e inquietos. [...] (p. 116) complementaridade capilar entre elas: as tranças brancas de uma e as madeixas escuras da outra enovelam-se quando nasce um fio branco na jovem. Não à toa, coube à idosa a iniciativa de detectar o que acontecera com os jacintos, enquanto os pais vagam pela casa e pelo jardim. A mãe apenas alisa os cabelos da filha, gesto carinhoso, mas ineficaz no sentido de compreender o que sucedera à adolescente. Sua atitude de segurar o castiçal reflete antes desnorteio do que entendimento, pouco ou nada remetendo ao mito da caverna. 0 papel efetivamente revelador compete à mulher mais velha e "boa conhecedora dos canteiros", das brenhas sob a ordenação floral do jardim. Ao mostrar a ruptura, a fratura exposta da vida ("o jacinto ainda vivo quebrado no talo"), a idosa evidencia o crescimento da neta, cifrado no fio branco que horroriza a família, incapaz de estancar a menina. Esse enfraquecimento do poderio paterno estampa-se sutilmente na menção à "casa dos jacintos", logo menos pertencente aos donos da propriedade.

Com isso, a habitação se aproxima do mundo natural e primitivo, sob cujo influxo a moça vira de novo menina. A regressão, paradoxalmente, a conduz ao amadurecimento. Essa osmose entre temporalidades também se verifica em contos de fadas, a exemplo de "Chapeuzinho vermelho", com a transferência da "atratividade sexual" ${ }^{32}$ entre avó e neta. O que Bettelheim limita à sexualidade - em sua opinião, avigorada pela forma pegajosa dos sapos ${ }^{33}$ - pode ser, em Clarice, alargado à dimensão subjetiva e identitária. O psicólogo observa que, ao contrário de João e Maria, sempre famintos, Chapeuzinho precocemente "ultrapassou sua fixação oral" ${ }^{34}$. Sem restringirmos o texto clariciano à psicanálise tão cerrada, é curioso a família começar o conto ao final do jantar, o que, flertando ou não com a superação da fase oral, certamente assinala a suspensão do cotidiano da sala de refeições. De fato, é notória a ausência de alimentos no conto: a boca da jovem de São Cristóvão abre-se não para a comida, mas para o grito que chancela sua autonomia, constituindo a voz mais alta registrada no texto.

No início do trecho acima transcrito, interpenetrando o velho e o juvenil, a avó segura um copo d'água, substância de frescor e vitalidade extensivos aos pontos de luz que se disseminam na casa, na flora e na fauna. Além disso, a narrativa se passa em maio, primavera no hemisfério Norte e outono no Sul. As duas estações caracterizam-se pela fertilidade das flores ou dos frutos. Situando a trama em cidade brasileira, Clarice alia a abundância do período outonal à sua contraparte destrutiva, a das folhas caídas. E a protagonista do "Mistério" frutifica justo a partir da perda daquilo que até então a circunscrevia à condição de filha-mais-velha-de-família-suburbana. Rompido o conforto da sala de jantar, da casa, dos jacintos, dos pais, de si, ela experimenta um "renascimento num plano mais elevado de existência" ${ }^{35}$, típico dos contos de fadas e ora pulverizado nas borboletas sonâmbulas. Entretanto, na contramão do destino redentor das donzelas arquetípicas, eternamente felizes, a moça carioca pode sempre lançar-se em novo abismo de auto(des)conhecimento, "o que sucederia talvez noutra noite de maio" (p. 117), conforme o desfecho do conto. Nisso ela e a avó empatam: ao 
arrepio de uma concepção evolucionista ou teleológica da existência, em que a velhice corresponderia à completude, a idosa e os pais também são afetados (mesmo que minimamente) pela epifania da garota: todos "tornaram-se atentos e inquietos", salvo as crianças, ainda pertencentes a tempo anterior à crise. Por isso, a sequência derradeira como que parodia a inicial: a luz inteiriça e tranquila torna-se difusa e agitada pelos castiçais à deriva no jardim até que, em último esforço de esclarecimento, os moradores "iluminaram a casa toda e passaram o resto da noite a esperar" (p. 116). 0 que preliminarmente era rotina caseira vira alerta e expectativa; o lar imantado pela mesa de jantar descerra-se literal e metaforicamente, à espreita de alguma interferência externa que coloque em xeque o "progresso naquela família que era frágil produto de muitos cuidados e de algumas mentiras" (p. 117). A "abastada cena" do começo evola-se perante a expectativa de uma "brisa da abastança" (p. 117). E o jardim, até então cândido e controlado reduto do aconchego burguês, ganha ares silvestres, pântano de mascarados e de espécies buliçosas ${ }^{36}$.

Desarticulados o jacinto e sua carga ilusória de proteção, a família recria o estatuto de normalidade ("tudo se desfez e teve que se refazer quase do princípio" [p. 117]), e a mocinha recupera a verdadeira idade. Todavia, esse recobro se revela imperfeito na medida em que, esfarelando a tranquilidade inaugural, o grupo adquiriu consciência de seu caráter construído, para não dizer artificial. Retorna a mecânica dos dias, mas se instaura a possibilidade ou a certeza de que ela é porosa a outros laços de famílias, firmados com sapos, galos, touros, homens e demônios.

\section{BIBLIOGRAFIA}

Vera Lucia ALBUQUERQUE DE MORAES, “O verde úmido subindo em mim: a mulher e a magia do jardim em Clarice Lispector”, Revista Interfaces, n.. 16 (janeiro-junho 2012), p. 49-58.

Stefan BACIU, “Apontamentos sobre três contistas brasileiros”, Letras e Artes: Suplemento Literário de A Manhã, 21/09/1952.

Nádia Battella Gotlib, Clarice: uma vida que se conta, 4. a edição, São Paulo, Ática, 1995.

Bruno BetTelheim, A psicanálise dos contos de fadas, 33. edição, São Paulo, Paz \& Terra, 2016.

Assis BRASIL, “O 'plot' no conto 3”, Suplemento Dominical do Jornal do Brasil, 29/08/1959, p. 4.

Antonio CANDIDO, “Uma tentativa de renovação", Brigada ligeira e outros escritos. São Paulo, Editora da UNESP, 1992.

Haroldo DE CAMPOS, "Introdução à Escritura de Clarice Lispector", Metalinguagem e outras metas, 2. a edição, São Paulo, Perspectiva, 2003.

Olga DE SÁ, A escritura de Clarice Lispector, 2..$^{a}$ edição, Petrópolis, Vozes; Lorena, Faculdades Integradas Teresa D’Avila, 1979.

Alexandre EULÁLIo, “Maio em São Cristóvão”, Livro involuntário, Rio de Janeiro, Editora da UFRJ, 1993, p. 156. 
“Letras e Artes", Diário Carioca, 30/12/1951, p. 3.

Letras e Artes: Suplemento Literário de A Manhã, 06/01/1952, p. 6.

“Letras e Artes”, Diário Carioca, 15/06/1952, p. 3.

Clarice LISPECTOR, A legião estrangeira: contos e crônicas, Rio de Janeiro, Editora do Autor, 1964.

Clarice LISPECTOR, Laços de família, Rio de Janeiro, Rocco, 1998.

Fábio LUCAS, “O conto Brasil moderno: 1922-1982”, Do barroco ao moderno, São Paulo, Ática, 1989.

Sergio MILLIET, “Prosa e verso", Letras e Artes: Suplemento Literário de A Manhã, 05/10/1952, p. 3.

Benedito NUNES, "O mundo imaginário de Clarice Lispector", O dorso do tigre, São Paulo, Editora Perspectiva, 1969.

Léo Gilson RIBEIRO, “Clarice Lispector - Tentativa de explicação", 2. caderno do Correio da Manhã, RJ, 21/3/1965, p. 5.

Affonso ROMANO de SANT’ANNA, "Laços de família e Legião estrangeira”, Análise estrutural de romances brasileiros. Petrópolis. Vozes, 1979

“Suplemento Literário”, Diário de Notícias, 20/09/1953, p. 3.

\section{NOTAS}

1. "Letras e Artes", Diário Carioca, 30/12/1951, p. 3.

2. Letras e Artes: Suplemento Literário de A Manhã, 06/01/1952, p. 6.

3. "Letras e Artes", Diário Carioca, 15/06/1952, p. 3.

4. Ştefan BACIU, "Apontamentos sobre três contistas brasileiros", Letras e Artes: Suplemento Literário de A Manhã, 21/09/1952, p. 5.

5. Id.

6. "Suplemento Literário", Diário de Notícias, 20/09/1953, p. 3.

7. Assis BRASIL, “O 'plot' no conto 3”, Suplemento Dominical do Jornal do Brasil, 29/08/1959, p. 4.

8. Léo Gilson RIBEIRo, "Clarice Lispector - Tentativa de explicação", 2. caderno do Correio da Manhã, Rio de Janeiro, 21/3/1965, p. 5.

9. Clarice LISPECTOR, A legião estrangeira: contos e crônicas, Rio de Janeiro, Editora do Autor, 1964, p. 173.

10. Alexandre EULÁLIo, "Maio em São Cristóvão", Livro involuntário, Rio de Janeiro, Editora da UFRJ, 1993, p. 156.

11. Antonio CANDIDO, "Uma tentativa de renovação", Brigada ligeira e outros escritos, São Paulo, Editora da UNESP, 1992, p. 99.

12. Sergio MiLliet, "Prosa e verso", Letras e Artes: Suplemento Literário de A Manhã, 05/10/1952, p. 3. 13. Affonso ROMANO DE SANT'ANNA, "Laços de família e Legião estrangeira”, Análise estrutural de romances brasileiros, Petrópolis, Vozes, 1979, p. 190.

14. Fábio LUCAS, “O conto Brasil moderno: 1922-1982”, Do barroco ao moderno, São Paulo, Ática, 1989, p. 131.

15. Olga DE SÁ, A escritura de Clarice Lispector, 2.. edição, Petrópolis, Vozes, Lorena, Faculdades Integradas Teresa D'Avila, 1979, p. 166.

16. Ibid., p. 167.

17. Ibid., p. 206. 
18. Haroldo DE CAMPOS, "Introdução à Escritura de Clarice Lispector", Metalinguagem e outras metas, $2^{\underline{a}}$ edição, São Paulo, Perspectiva, 2003, p. 186.

19. Clarice LISPECTOR, A legião estrangeira: contos e crônicas, p. 172-3.

20. Clarice LISPECTOR, "Mistério em São Cristóvão", Laços de família, Rio de Janeiro, Rocco, 1998, p. 112. Todas as referências ao conto estudado se referem a essa edição e serão citadas diretamente no texto a partir de agora.

21. Vera Lucia ALBUQUERQUE DE MORAES, "O verde úmido subindo em mim: a mulher e a magia do jardim em Clarice Lispector", Revista Interfaces, ํo 16 (janeiro-junho 2012), p 54.

22. Benedito NUNES, "O mundo imaginário de Clarice Lispector", 0 dorso do tigre, São Paulo, Editora Perspectiva, 1969, p. 88.

23. Alexandre EULÁLIO, op. cit., p. 157.

24. Para detalhes sobre a história de São Cristóvão, ver Lená MEDEIROS DE MENEZES, "Imigração Portuguesa: lembranças de terras distantes. Tijuca e São Cristóvão como estudo de caso", Revista do Arquivo Geral da Cidade do Rio de Janeiro, n. 6 (2012), p.79-95.

25. Nádia Battella Gotlib, Clarice: uma vida que se conta, 4. edição, São Paulo, Ática, 1995, p. 136.

26. Bruno BEtTelheim, A psicanálise dos contos de fadas, 33. edição, São Paulo, Paz \& Terra, 2016,

p. 313.

27. Ibid., p. 315.

28. Ibid., p. 241.

29. Ibid., 113.

30. Bruno BETTELHEIM, op. cit., p. 322.

31. Id.

32. Bruno BETTELHEIM, op. cit., p. 242.

33. Ibid., p. 397.

34. Ibid., 239.

35. Ibid., 241.

36. Para o motivo do jardim em Clarice Lispector, ver Vera Lucia ALBUQUERQUE DE MORAES, op. cit.

\section{RESUMOS}

Cet essai propose une analyse littéraire minutieuse de l'épiphanie dans «Mistério em São Cristóvão ", de Clarice Lispector. Pour ce faire, nous examinerons les aspects plastiques de la configuration de l'espace narratif, la caractérisation symbolique des personnages, la richesse morphosémantique, ainsi que quelques intertextualités présentes dans le récit.

This essay proposes a close reading of the textual construction process of the epiphany in the short story "Mistério em São Cristóvão", by Clarice Lispector. For that, we will examine the narrative space's plastic aspects, the symbolic characterization of the characters, the richness of the morphosemantic stratum, as well as some intertextualities established by the text. 
ÍNDICE

Mots-clés: littérature brésilienne, Clarice Lispector, Laços de família, Mistério em São Cristóvão, épiphanie

Keywords: Brazilian Literature, Clarice Lispector, Laços de família, Mistério em São Cristóvão, epiphany

\section{AUTOR}

\section{GILBERTO ARAÚJO}

Universidade Federal do Rio de Janeiro 